Abstracta Iranica Abstracta Iranica

Revue bibliographique pour le domaine irano-aryen

Volume 26 | 2005

Comptes rendus des publications de 2003

\title{
«Relations between the Safavid State and its Non- Muslim Minorities ». Islam and Christian-Muslim Relations 14, 4 (2003), pp. 435-458.
}

\section{Colin Mitchell}

\section{(2) OpenEdition}

1 Journals

Édition électronique

URL : http://journals.openedition.org/abstractairanica/2829

ISSN : 1961-960X

Éditeur :

CNRS (UMR 7528 Mondes iraniens et indiens), Éditions de l'IFRI

Édition imprimée

Date de publication : 15 mai 2005

ISSN : 0240-8910

\section{Référence électronique}

Colin Mitchell, « «Relations between the Safavid State and its Non-Muslim Minorities ». Islam and Christian-Muslim Relations 14, 4 (2003), pp. 435-458. », Abstracta Iranica [En ligne], Volume 26 | 2005 document 245, mis en ligne le 08 décembre 2005, consulté le 25 septembre 2020. URL : http:// journals.openedition.org/abstractairanica/2829

Ce document a été généré automatiquement le 25 septembre 2020.

Tous droits réservés 


\title{
« Relations between the Safavid State and its Non-Muslim Minorities ». Islam and Christian- Muslim Relations 14, 4 (2003), pp. 435-458.
}

\author{
Colin Mitchell
}

The eminent Safavid historian Roger Savory offers here a concise exploration of the status and treatment of non-Muslims during the Safavid period (1501-1722) of Iran. In addition to a short overview of Islamic juridical justifications for the second-class status of Jews, Christians, Zoroastrians, and Sabeans living under Islamic rule, Savory provides a brief synopsis of the rise of Mongol ecumenical policies in 13th and 14th century Iran and their subsequent disappearance during the internecine politics during the Timurid and Turkmen periods of the 15th century. Savory contends that the advent of a shi' ite state introduced a new dynamic to the age-old issue of relations between an Islamic state and its non-Muslims subjects, namely the peculiarly shi'ite doctrine of naj $\bar{a} s a t$ ("ritual impurity"). According to Savory, this disdain for impure substances, both animate and inanimate, had strong ramifications for the treatment of 'unclean' Jews and Christians during reign of the increasingly orthopraxic Šāh Țahmāsp. Undoubtedly, the issue of non-Muslims in the Safavid state would become central during the reign of Šāh 'Abbās, a ruler who opened up Iran to European commercial agents and Catholic religious institutions after the turn of the 16th century. Savory does distinguish between how foreign non-Muslims such as the Carmelite and Augustinian ecclesiastics were treated and those Jews and Christian Armenians and Georgians who were considered the shah's subjects. While 'foreign' non-Muslims were generally welltreated, 'domestic' non-Muslims such as the Armenian and Georgian Christians were generally tolerated well but did suffer the occasional persecution, forced conversion, and coerced relocation. This appears to have been the case until the reign of 'Abbās II and the vazirate of Muhammad Beg (an Armenian convert to Islam) when it was 
decreed that up to 100,000 Jews across Iran were to be forcibly converted to shi' ite Islam. Intolerance became more widespread during the subsequent reigns of Šāh Sulaymān and Šāh Sulțān Ḥusayn. Large numbers of Zoroastrians and Jews were forced to reject their own faiths and embrace Islam, and by the beginning of the 18th century, most foreign non-Muslims had left Isfahan.

INDEX

Thèmes : 4.2.1. Safavides et Qâjârs

\section{AUTEURS}

COLIN MITCHELL

Dalhousie University - Halifax 